\title{
The Influential Factors on Capital Adequacy Ratio in Iranian Banks
}

\author{
Leila Bateni $^{1}$, Hamidreza Vakilifard ${ }^{1} \&$ Farshid Asghari $^{2}$ \\ ${ }^{1}$ Economics and Management Department, Science and Research Branch, Islamic Azad University, Tehran, \\ Iran \\ ${ }^{2}$ School of Economics, Payame-Noor University, Tehran, Iran \\ Correspondence: Leila Bateni, Economics \& Management Department, Islamic Azad University, Science and \\ Research Branch, Hesarak, Tehran, I. R. Iran. Tel: 98-919-355-8656. E-mail: batenileila@gmail.com
}

Received: June 9, 2014

doi:10.5539/ijef.v6n11p108
Accepted: July 6, 2014

Online Published: October 25, 2014

URL: http://dx.doi.org/10.5539/ijef.v6n11p108

\begin{abstract}
One of essential requirements for banks and financial institutions is adequate and sufficient capital and every banks and financial organizations must keep balance between capital and available risk in its assets in order to guarantee its stability. Thus it has become one of the most important criteria for depository institutions. This study focuses on influential factors (precisely seven financial factors) over capital adequacy in Iranian private banks for the period 2006-2012. The results obtained indicate negative relationship between bank size and capital adequacy ratio of banks and positive relationship between Loan Asset Ratio (LAR), Return on Equity (ROE), and Return on Asset (ROA), Equity Ratio (EQR), and capital adequacy ratio. RAR and DAR do not have any impact on capital adequacy ratio.
\end{abstract}

Keywords: Capital Adequacy Ratio (CAR), Loan Asset Ratio (LAR), Deposit Asset Ratio (DAR), Risk Asset Ratio (RAR), Equity Ratio (EQR)

\section{Introduction}

Capital adequacy ratio is one of the most significant current issues in banking which evaluate the amount of a bank's efficiency and stability. The Basel Capital Accord is an international standard for the calculation of capital adequacy ratios. The Accord recommends minimum capital adequacy ratios that banks should meet. Using minimum capital adequacy ratios causes promotion in stability and efficiency of the financial system by decreasing the likelihood of insolvency in banks. In the aftermath of the financial crisis, there have been efforts by regulatory authorities to make banks stronger. To accomplish this, governments across the developed world are enforcing strengthen their balance sheets by increasing capital, and if they cannot raise more capital, they are told to decrease the amount of risk assets (loans) on their books. (Abba, 2013). In 2010, the world's central bankers, represented collectively by the Bank of International Settlements (BIS) handed down Basel III-a global regulatory framework that, among other things, raise minimum capital requirements from $4 \%$ to at least $7 \%$ of a bank's risk-weighted assets (Hanke, 2013). Capital adequacy as a concept has been in existence prior to the era of capital regulation in the banking industry and there exist several literatures on the determination of capital adequacy ratio (CAR) as well as its determinants. The concept appeared in the middle of the 1970's because of the expansion of lending activities in banks without any parallel increase in its capital, since capital ratio was measured by total capital divided by total assets (Al-Sabbagh, 2004). This led to the evolution of international debt crisis and the failure of one of the biggest American banks, Franklin National Bank (Koehn \& Santomero, 1980). These events forced regulatory authorities to stress more control procedures and to improve new criteria and methods to avoid bank's insolvency (Al-Sabbagh, 2004). Capital adequacy generally affects all entities. But as a term, it is most often used in discussing the position of firms in the financial section of the economy, and precisely, whether firms have sufficient capital to cover the risks that they confront (Abba, 2013).

Capital adequacy ratio for banking organizations is an important issue that has received a considerable attention in finance literature. According to Al-Sabbagh (2004), capital adequacy is described as a indicator of bank's risk exposure. Banks risk is classified into different risk include credit risk, market risk, interest rate risk and exchange rate risk that are considered in the CAR calculation. Therefore regulatory authorities used capital adequacy ratio as a significant indicator of "safety and stability" for banks and depository institutions because they view capital as a guard or cushion for absorbing losses (Abdel-Karim, 1964). 
Purpose of Capital adequacy is facilitating financial stability and, as a result, the role of an individual institution in and internationally is financial stability since it increases the level of risks in the activities of banks because of the system is the central issue.one of the most significant current discussions in financial sectors, both domestically the relationship between banking activities and other parts of the financial section is increasing deeply, there is the possibility of financial stability being disrupted by non-banking activities. Since it increases the level of risks in the activities of banks. Yu Min-Teh (1996) studied capital adequacy for banks as the level at which the deposit insuring agency would just breakeven in guaranteeing the deposits of individual banks with the premium the bank pays. He used data from depository institutions in Taiwan, during 1985-1992 for measuring fair capital adequacy. Sharpe (1977) defined capital as a difference between assets and deposits, so the larger the ratio of capital to assets (or the ratio of capital to deposit) the safer the deposits. As capital was adequate, deposits were "safe enough". His idea was that if the value of an institution's assets may decline in the future, its' deposits will generally be safer, the larger the current value of assets in relation to the value of deposits.

Dowd (1999) found in his study that the minimum capital standards on financial institutions can be seen as a means for reinforcing the security of deposits and robustness of the banking system. Also, Harold (1999) found the same result as Dowd, in that many regulators and depositors were concerned about the security of deposit insurance system. His study applied existing bank risk-based capital requirements to current credit union data to evaluate credit union's risk-based capital strength.

Many researchers have worked on capital adequacy. A number of researchers have provided insights, theoretical as well as empirical, into the capital adequacy. A short review of the studies focusing on developed and emerging capital markets is presented in this paper. Modigliani and Miller (1958) provide evidence about proficiency of financial markets and capital structure. Santomero and Watson (1977) indicate that too tight a capital regulation lead banks to reduce their credit offer and, as a result, give rise to a fall in productive investment (Barrios \& Blanco, 2003). They argue that, from society's viewpoint, the optimal level of bank's capital should be specified by the point at which the marginal public returns to bank capital (decreased chances of failure and decreased chances of disruption of the payments system) exactly equal the marginal public costs of bank capital (the opportunity cost of diverting capital from other productive uses). Under some legal and political structures, however, regulators may not consider the social costs and, therefore, will impose more capital in the system than society may desire. Short provides an excellent graphical presentation. They address the question of capital adequacy macro/banking system level (Morgan, 1984). Marcus (1983) explained the dramatic decrease in capital to asset ratio in U.S commercial banks during the last two decades. He indicated that the rise in nominal interest rates have contributed to the fail in capital ratios.

Jeff (1990) gave an overview of capital requirements for banks and financial institutions showing that there was no difference in capital standards for these two types of financial institutions. He said that capital adequacy was reflected in asset size as a proxy of a well-managed bank. This gave benefits for strongly capitalized banks according to poorly capitalized banks which will sell assets to raise capital. In I990's capital adequacy has become the major benchmark for financial institutions. And it was considered as a primary measure for safety and soundness. Jeff was also regards the return on assets (ROA) ratio as a major indicator of a well-managed bank. Bensaid et al. (1995) consider the capital requirement in the context of both adverse selection and moral hazard. Adverse selection arises as the quality of the bank's assets is private information to the bank's owners, and moral hazard arises as the bank's profit depend on the unobservable effort chosen by the banker. Song (1998) examined Korean banks' responses to the Basel risk weighted capital adequacy requirements implemented in 1993. The author concluded that the higher capital requirements were generally effective because Korean banks generally did not much utilize "cosmetic" adjustments to increase their capital ratios.

Reynolds et al. (2000) studied financial structure and bank performance from 1987 to 1997. They have examined the financial structure and performance of banks in Asian Countries and found that profitability and loan preferences increases with size, but capital adequacy have negative relationship with size, so large banks have smaller capital adequacy ratios, and more profitable banks have more capital adequacy. Yu (2000) studied bank size; liquidity and profitability are the main influential factors of bank capital ratio in Taiwan. The author summarized that large banks in Taiwan have much lower capital ratios than the small banks which is consistent with the previous study where the large banks do not think about fail because they are big enough. The author also recommended that the banks mainly use internal source of capital, this contributes that profitability and (CAR) have positive relationship. The remarkable finding of this paper is the positive relationship between the equity-to-asset ratio and the liquidity ratio for small banks, but significantly negative for medium size banks. Aggarwal and Jacques (2001) reported that US banks increased their capital ratio without increases in credit 
risk. They concluded that the prompt corrective action positively and significantly affected capital ratio in both high capital and low capital banks with a faster speed of adjustment in undercapitalized banks. Rime (2001) investigated relationship between banks' capital and risk behavior in Swiss. The author adopts a simultaneous equations approach to examine whether Swiss banks which close to the minimum regulatory standards have desire to raise their capital ratio. He recommends that regulatory pressure and capital ratio has a positive and significant relationship. However, there is no evidence of capital requirement has significant effect on the banks' risk taking behavior. Saunders and Wilson (2001) suggested that the relationship between charter value and capital structure decisions is procyclical. Their regression results showed that during economic booms situation, high charter value banks possess a higher capital ratio. Nevertheless, during economic recessions, higher charter value banks uphold higher losses of charter value. The most important finding of this paper is that charter value may not able to lessen the amount of risky activities that banks involved.

Morrison and White (2001) state that capital adequacy requirements are beneficial mainly in restricting bank size to be small enough to avoid risky problems. Tanaka (2002) analyzes the impact of bank capital adequacy requirement on the monetary transmission mechanism. The results suggest that applying a general equilibrium frame-work and a representative bank, the pattern indicates that the monetary transmission mechanism is attenuated if banks are poorly capitalized or if the capital adequacy requirement is stringent. In addition, it predicts that Basel II may decrease the effectiveness of monetary policy as a mean for motivating output during recessions.

Ghoshi et al. (2003) found that Indian banks have not categorized to assets replacement across the risk-weight classes by exchange low risk government securities for high risk loans in order to meet their capital requirement. This show that capital regulation does influence the banks decisions making. Chen (2003) re-views the capital adequacy regulation of Chinese banks. He finds that while government support is asserted to be the invisible treasure of state banks, capital increase is always desired and the most practical method is applying subordinated debt to raise their additional capital. Chami and Cosimano (2003) show that the overemphasis by regulators and market practitioners on Tier I or equity capital as the relevant constraint for banks is not necessarily supported by the Basel Accord. They show, in contrast, that the Basel Accord intended for total capital-a minimum of $8 \%$ - and not for equity capital to be the binding constraint. Navapan and Tripe (2003) described that comparing banks' return on equity is one method of evaluating their performance. They proved that the thesis that there should be a negative relationship between a bank's ratio of capital to assets and its ROE may seem to be apparent. They indicated there is a negative relationship between capital and profitability. Thampy (2004) shows the impact of capital adequacy regulation on loan growth. Since loans have the highest risk weight, a capital constrained bank would want to conserve its capital by allocating fewer assets to loans. This trend becomes more severe as the capital constraint becomes binding which is the case for banks with less than the required capital level. However, for banks with high capital adequacy ratios, there is little impact on loan growth. He also shows that in a capital constrained environment banks will reduce the supply of loans. It also provides an explanation for the high proportion of investments held by banks. The reduction in the supply of loans is greater for banks which are inefficient. The effect of higher capital standards on the reserve of bank credit in the economy would have a greater impact in economies which have a bank dependent or dominated financial system as opposed to a capital markets dominated system. Asarkaya and Özcan (2007) analyzed the influential factors of capital structure in the Turkish banks. They suggested an empirical model in order to explain why banks hold capital more than the requirement. They used a data covering the period 2002-2006. The findings of their study suggested that lagged capital, portfolio risk, economic growth, average capital level of the sector and ROE have positive relationship with capital adequacy ratio and share of deposits have negative relationship with capital adequacy ratio. Ahmad et al. (2009) reported new findings on influential factors of bank capital ratios in Malaysia. This study indicates there is a positive relationship between regulatory capital and banks' risk taking behavior. The study also observes that capital requirement regulations introduced in 1996 was ineffective whereas those mandated in 1997 are proved successful in the financial crises period. Also, the study finds inconsistency with developed country literature where results shows that bank capital ratios not to been motivated by bank profitability. Toby (2008) investigated the impact of bank liquidity management practices on industry asset quality. He also examined the impacts of capital adequacy regulation on selected bank asset quality and efficiency measures. He showed that applying of the minimum liquidity ratio is irrelevant in controlling industry non-performing loans.

Mathuva (2009) indicates that bank profitability has positive relationship with the core capital ratio and tier 1 risk based capital ratio. The study, applying the ROA and ROE as proxies for bank profitability for the period 1998 to 2007, also states that there is a negative relationship between the equity capital ratio and equity. Ho and 
Hsu (2010) investigate the relationship between firms' financial structures and their risky investment strategy in Taiwan banks. Their first result indicates that the restrictions on capital adequacy ratio have really affected firms' risky investment strategies, as market share and leverage have positive relation. Second, the firm performance has positive relationship with firm size, leverage and financial cost. Finally, the regression results show that financial structures for banking firms have positive relationship with the states of business cycle.

There is therefore no gainsaying the fact that there are several researches that have provided evidences of Detriments of capital adequacy in other countries. However, there has been little research in this area in Iran. Therefore the problem here is to use the multiple regression model to investigate whether there is significant relationship between capital adequacy ratio and financial indicators in the Iranian banking industry. Furthermore, it has been observed that there have not been significant researches on the relationship between capital adequacy and financial factors in Iran. Thus, this study is an attempt to fill the identified gaps. Against this backdrop, the purposes of the study are: to empirically investigate the relationship between financial ratios and capital adequacy ratio; to analyze and evaluate the influential factors of capital adequacy ratio; to investigate the components of banks capital and to establish a capital adequacy forecasting pattern which will be beneficial to both authoritarians and the banking system in general for formulating informed courses of action. In line with the above, the following statements of hypotheses have been provided for this study:

H01: There is no significant relationship between bank's size and capital adequacy ratio.

H02: There is no significant relationship between Loan Asset Ratio (LAR) and capital adequacy ratio.

H03: There is no significant relationship between Equity Ratio (EQR) and capital adequacy ratio.

H04: There is no significant relationship between Return on Equity (ROE) and capital adequacy ratio.

H05: There is no significant relationship between Deposit Asset Ratio (DAR) and capital adequacy ratio.

H06: There is no significant relationship between Return on Asset (ROA) and capital adequacy ratio.

H07: There is no significant relationship between Risk Asset Ratio (RAR) and capital adequacy ratio.

\section{Method}

\subsection{Data Description and Variable Definitions}

The aim of this study is to investigate the influential factors of Iranian banks' capital adequacy ratio. The secondary data used in this study and we aggregate the data from annual reports of the sample banks. Data directly took from the private banks' balance sheet statement, profit and loss statement and from notes to account. Time study period is seven years from 2006 to 2012. In Iran have a population of 18 banks comprising 8government-owned banks, 7 privately-owned banks, 3 saving banks founded in Iran. The study focuses on private banks on Iran which there has been access to their financial statements. After this selection, our final sample includes 6 banks. Panel data methodology is used in this study and analyze relationships between bank specific variables [bank size (SIZE), Loan Asset Ratio(LAR), Return on Equity(ROE),Deposit Asset Ratio(DAR), Risk Asset Ratio (RAR), Return on Asset (ROA), Equity Ratio (EQR)and a dependent variable which is capital adequacy ratio (CAR)]. The total capital requirement requires a total risk-weighted capital adequacy ratio of 8 per cent is used as the proxy for bank capital adequacy ratio in this study. CAR is calculated according to the Formula 1, presented as below:

$$
\begin{aligned}
& \mathrm{CAR}=\frac{\text { Tier } 1 \text { Capital }+ \text { Tier } 2 \text { Capital }}{\text { Risk Weighted Assets }} \\
& \mathrm{CAR}=\frac{\text { Shareholders' Equity }}{\text { Amount Subject to Credit Risk }+ \text { Amount Subject to Market Risk }+ \text { Amount Subject to operational Risk }} \\
& \text { Explanatory variables and hypotheses: }
\end{aligned}
$$

2.1.1 Bank size (SIZE)

There are various methods to assertion the firm size. For example, someone uses market values of equity of the firm. Sometimes the sell value of the firms is used for firm's size. Like Ellul and Pagano (2006) in this research, the total asset is utilizing as the firm size and because the firm size is very bigger than other variables, we use a logarithm of total asset to bring it near to the other variable size.

\subsubsection{Loan Asset Ratio (LAR)}

The loan to assets ratio measures the total loans outstanding as a percentage of total assets. The higher this ratio indicates bank liquidity is low. The higher the ratio, the more risky a bank may be to higher defaults. LAR is calculated according to the Formula 2, presented as below: 


\subsubsection{Equity Ratio (EQR)}

Although leverage (capitalization) has been indicated to be essential in describing the performance of financial institutions, its effect on bank profitability is equivocal. As lower capital ratios suggest a relatively risky position, one might expect a negative coefficient on this variable (Berger, 1995). An enhancement in capital may increase expected earnings by decreasing the expected costs of financial distress; including bankruptcy (Berger, 1995). Capital is measured as total capital and reserves as reported in the balance sheet. EQR is calculated according to the Formula 3, presented as below:

$$
E Q R=\text { Total Equity/Total Assets }
$$

\subsection{4 (ROE) and (ROA)}

In this study return on assets and return on equity are used as a proxy for profitability. Profitability is expected to have positive relationship with capital adequacy ratio because a bank is anticipated to have to raise asset risk in order to get higher returns in most cases. Gropp and Heider (2007) indicated a positive relationship between profit and capital relative to assets. ROA is a ratio of net income to total assets for the bank. ROE is a ratio of net income to shareholder's equity of a bank.

\subsubsection{Deposit Asset Ratio (DAR)}

Yu Min-Teh (1996) defined adequate capital for banks as the level at which the deposit guaranteeing agency would just breakeven in insuring the deposits of individual banks with the premium the bank pays. Sharpe (1977) defined capital as a difference between assets and deposits, so the larger the ratio of capital to assets (or the ratio of capital to deposit) the safer the deposits. As capital was adequate, deposits were "safe enough". His idea was that if the value of an institution's assets may decline in the future, its' deposits will generally be safer, the larger the current value of assets in relation to the value of deposits. Dowd (1999) found in his study that the applying minimum capital standards on financial institutions can be seen as a means of reinforcing the safety of deposits and robustness of the banking system. DAR is calculated according to the Formula 4, presented as below:

$$
\text { DAR= Total Deposits/ Total Assets }
$$

\subsubsection{Risk Asset Ratio (RAR)}

The Risk Asset Ratio evaluates the amount of a bank's total regulatory capital in relation to the amount of risk it is taking. The idea is that all banks must assure that a reasonable proportion of their risk is guarded against by permanent capital. Banks must keep a minimum RAR (total capital ratio) of 8\%. Effectively, this means that $8 \%$ of the risk-weighted assets must be guarded against by permanent or near permanent capital. The higher the capital adequacy ratios a bank has, the greater the level of unanticipated losses it can absorb before insolvency? So the less risky it should be. Also known as the solvency ratio. RAR is calculated according to the Formula 5.

$$
R A R=\text { Risky Weighted Assets/Total Assets }
$$

\subsection{Econometric Model}

This study investigated the impacts of bank specific variables on capital adequacy ratio by applying a multivariate regression model. This model was beneficial and appropriate because the research focus is examining the simultaneous relationships between capital adequacy ratio and bank specific variables. Based on both theoretical and empirical literature reviewed, this study hypothesize the model between CAR and seven bank specific variables, namely SIZE, LAR, EQR, ROA, ROE, RAR and DAR. The regression model of the study is:

$$
C A R=\beta_{0}+\beta_{1} \operatorname{SIZE}_{i t}+\beta_{2} L A R_{i t}+\beta_{3} E Q R_{i t}+\beta_{4} R O A_{i t}+\beta_{5} R O E_{i t}+\beta_{6} R A R_{i t}+\beta_{7} D A R_{i t}+\varepsilon_{i t}
$$

In the above equation $\beta_{0}$ is constant and $\beta$ shows coefficient of variables while is the residual error of the regression. The multivariate regression method is applied to estimate the regression model stated above and all estimations have been performed in the econometrical software program EVIEWS.

\section{Results}

Table 1 includes the descriptive statistics of the under-studying data for using in Regression. According to this fact that the statistical data \& information were extracted from the data of 6 private banks during 2006 to 2012 , so each of the variables can have 41 observations. The observed calculated descriptive statistics consist of minimum, maximum, mean, median, Standard Deviation, skewness, kurtosis as well as the Jarque-Bera statistics and probabilities (p-values). As it can be seen from the Table 1, all the variables are asymmetrical. 
Especially, skewness is positive for four series, While, SIZE, RAR, DAR, and ROE have a negative skewness. Kurtosis value of all variables also indicates data is not normally distributed because values of kurtosis are deviated from 3. The measure of Jarque-Bera statistics and corresponding p-values are used to test for the normality assumption. Based on the Jarque-Bera statistics and p-values this assumption is rejected at 5\% level of significance for variables. The dependent and independent variables are examined for multicollinearity based on a simple correlation matrix. As depicted in Table 2, all of them are have no collinearity problem. Having concluded that none of the bank specific variables are highly correlated and no multicollinearity amongst these variables exist; the effect of bank specific bank variables on the capital adequacy ratios is examined by the Panel Data estimation. The regression results of panel data are reported in Table 3.

Table 1. Descriptive statistics of study variables

\begin{tabular}{lllllllll}
\hline variables & CAR & SIZE & LAR & EQR & ROA & ROE & RAR \\
\hline Mean & 14.05978 & 7.702146 & 61.87317 & 14.96922 & 2.540195 & 25.36673 & 73.06329 & 75.71805 \\
Median & 11.26800 & 7.693000 & 64.91300 & 7.603000 & 2.163000 & 25.90700 & 73.17700 & 82.81900 \\
Maximum & 45.41610 & 8.495000 & 75.13000 & 96.94700 & 7.727000 & 51.59500 & 89.03100 & 92.11600 \\
Minimum & 7.304000 & 6.563000 & 2.680000 & 4.379000 & 0.766000 & 2.087000 & 21.35900 & 0.602000 \\
Std. Dev. & 8.328375 & 0.487633 & 14.34558 & 19.69161 & 1.249096 & 9.814368 & 12.51601 & 19.10946 \\
Skewness & 2.490685 & -0.448416 & -2.736154 & 3.035496 & 1.901440 & -0.127871 & -2.060446 & -2.526044 \\
Kurtosis & 9.461492 & 2.551696 & 10.51315 & 11.41450 & 8.386434 & 3.476616 & 9.165016 & 9.120633 \\
Jarque-Bera & 113.7151 & 1.717358 & 147.5891 & 183.9204 & 74.27074 & 0.499802 & 93.93983 & 107.6006 \\
Probability & 0.000000 & 0.023722 & 0.000000 & 0.000000 & 0.000000 & 0.008878 & 0.000000 & 0.000000 \\
Observatios & 41 & 41 & 41 & 41 & 41 & 41 & 41 \\
\hline
\end{tabular}

The dependent variable (CAR) is the capital adequacy ratio. Model correspond to cross-section fixed effects. The model is estimated using a panel of 42 observations for the period 2006 to 2012 derived from 6 Iranian banks. The estimated coefficients are also assigned for the banks with the aim of capturing the influence of specific characteristics of each individual bank.

Table 2. The pairwise correlation matrix for dependent (CAR) and explanatory variables

\begin{tabular}{lcccccccc}
\hline & CAR & SIZE & LAR & EQR & ROA & ROE & RAR & DAR \\
\hline CAR & 1.000000 & & & & & & & \\
SIZE & -0.451393 & 1.000000 & & & & & & \\
LAR & -0.513240 & 0.661059 & 1.000000 & & & & & \\
EQR & 0.598192 & -0.626850 & -0.936903 & 1.000000 & & & & \\
ROA & 0.486068 & -0.305294 & -0.438361 & 0.469993 & 1.000000 & & & \\
ROE & -0.545756 & 0.324456 & 0.584234 & -0.667524 & -0.105293 & 1.000000 & & \\
RAR & -0.153359 & 0.464862 & 0.732423 & -0.675928 & -0.044142 & 0.409420 & 1.000000 & \\
DAR & -0.562617 & 0.613724 & 0.880568 & -0.948388 & -0.400401 & 0.717915 & 0.614534 & 1.000000 \\
\hline
\end{tabular}

Then, we extended the regression results in order to select which model is better; fixed effects or random effects model. One common method for testing this assumption is to use a Hausman (1978) test to compare the fixed and random effects estimates of coefficients (Baltagi, 2001; Wooldridge, 2002). The purpose is to find out whether there is significant correlation between the unobserved individual specific random effects ( $\alpha \mathrm{i})$ and the regressors. The result of Hausman test is indicated in Table 4 suggested that the corresponding effects are statistically significant, hence the null hypothesis is rejected by our data and fixed effects model is preferred.

As Table 3, 2nd column reports the adjusted R Square value (0.7115) suggest that model serves its purpose in determining the impact of specific variables on capital adequacy ratio. In other words, $71.15 \%$ variability of the capital adequacy ratio can be explained by the SIZE, LAR, DAR, RAR, ROA, ROE, and EQR. Before analyzing the coefficients, one should look at the diagnostics of regression. In this matter, Durbin-Watson (DW) statistic can show us the serial correlation of residuals. As a rule of thumb, if the DW statistic is less than 2, there is evidence of positive serial correlation. The DW statistic in our output is 2.46 and this result confirms that there is no serial correlation. With computed F-value of $16.1010(\mathrm{p}<0.000)$ for the panel data regression, we reject the null that all coefficients are simultaneously zero and accept that the regression is significant overall. 
As it can be seen from the Table 3, RAR and DAR do not have any impact on capital adequacy ratio. SIZE has a significant and negative relationship with capital adequacy ratio .this result represents that large Iranian banks have lower regulations than small size banks. LAR has a significant and positive effect on capital adequacy ratio. We found a positive significant relationship between CAR and EQR. ROA has a significant and positive relationship with capital adequacy ratios. The coefficient of ROA indicates that a one unit increase in profitability increases the bank capital by 0.418 units according to the Table 3 . On the other hand, ROE has a significant and negative relationship with CAR. The coefficient of ROE indicates that a one unit increase in profitability decreases the bank capital by 0.101 units according to the Table 3 . To sum up our results, SIZE, LAR, ROA, ROE and EQR seem to affect CAR. On the other hand, DAR and RAR do not appear to have significant effects on capital adequacy ratios.

Table 3. Panel regression results (Dependent variable: CAR)

\begin{tabular}{ll}
\hline Explanatory variable & \{Cross-Section (Fixed Effects) \\
\hline CONSTANT & $23.601(2.515)^{*}$ \\
SIZE & $-0.135(-3.761)^{*}$ \\
LAR & $0.138(1.841)^{* *}$ \\
DAR & $0.043(0.516)$ \\
ROE & $0.101(2.341)^{* *}$ \\
ROA & $0.418(5.682)^{*}$ \\
EQR & $0.208(1.649)^{* *}$ \\
RAR & $-0.31(0.204)$ \\
& $42($ balanced) \\
R2 & 0.7115 \\
Adj. R2 & 0.6717 \\
F-Stat. & $16.1010^{*}$ \\
Durbin-Watson Stat. & 2.4618 \\
\hline
\end{tabular}

Note. Values in parentheses are the standard errors. *and ** denote significant level at 1 and 5 respectively.

Table 4. Hausman test for correlated random effects

\begin{tabular}{llll}
\cline { 2 - 4 } Test cross-section random effects & Chi-Sq. Statistic & Chi-Sq. d.f. & Probability \\
\hline Cross-section random & 50.630937 & 5 & 0.00000 \\
\hline
\end{tabular}

Note. $\mathrm{H} 0: \alpha_{\mathrm{i}}$ are uncorrelated with $\mathrm{X}_{\mathrm{it}} ; \mathrm{H} 1 ; \alpha_{\mathrm{i}}$ are correlated with $\mathrm{X}_{\mathrm{it}}$.

\section{Conclusions}

The main objective of the present paper is to investigate empirically determinants of CAR in Iranian banks and its effects on financial positions of banks covered by the study. This study used secondary data and we aggregate the data from annual reports of the sample banks. Data directly taken from the private banks balance sheet statement, profit and loss statement and from notes to account. Time study period is seven years, from 2006 to 2012. Panel data regression is used in this study and analyzes relationships between bank specific variables: SIZE, LAR, RAR, DAR, ROA, ROE, EQR and a dependent variable which is CAR. The results of the paper indicates that CAR to be adversely affected by bank's SIZE, this means that large Iranian banks have low supervisory control on their capital adequacy ratio (CAR), and large banks attain a high risk assets portfolio, represented in a positive relationship between RAR and SIZE, while EQR, ROA, ROE and LAR positively influence CAR, While, RAR and DAR do not have any significant relationship with CAR.

\section{References}

Abba, G. O., Zachariah, P., \& Inyang, E. E. (2013). Capital Adequacy Ratio and Banking Risks in the Nigeria Money Deposit Banks. Research Journal of Finance and Accounting, 4(17), 17-25. Retrieved from http://www.iiste.org/Journals/index.php/RJFA/article/view/8972

Abdel Karim, R. A. (1996). The Impact of the Basel Capital Adequacy Ratio Regulation on the Financial and Marketing Strategies of Islamic Banks. International Journal of Bank Marketing, 32-44. http://dx.doi.org/10.1108/02652329610151368 
Aggarwal, R., \& Jacques, K. T. (2001). The impact of FDICIA and prompt corrective action on bank capital and risk: estimates using a simultaneous equations model. J. Bank. Finan., 25, 1139-1160. http://dx.doi.org/10.1016/S0378-4266(00)00125-4

Ahmad, R., Ariff, M., \& Skully, M. J. (2009). The determinants of bank capital ratios in a developing economy. Asia-Pac. Finan. Mark., 3(4), 255-272. Retrieved from http://www.carf.e.u-tokyo.ac.jp/pdf/workingpaper/fseries/152.pdf

Al-Sabbagh, N. (2004). Determinants of capital adequacy ratio in Jordanian banks. Master thesis, Yarmouk University. Irbid, Jordan. 30 March.

Asarkaya, Y., \& Özcan, S. (2007). Determinants of capital structures in financial industries: The case of Turkey. 91-109. Retrieved from http://www. bddk.org.tr/websitesi/turkce/Raporlar/BDDK.../3885makale5.pdf

Baltagi, B. H. (2001). Econometric analysis of panel data (2nd ed.). New York: John Wiley \& Sons.

Barrios, V. E., \& Blanco, J. M. (2003). The effectiveness of bank capital adequacy regulation: a theoretical and empirical approach. J. Bank. Finan., 27, 1935-1958. http://dx.doi.org/10.1016/S0378-4266(02)00311-4

Bensaid, B., Pages, H., \& Rochet, J. C. (1995). Efficient regulation of bank's solvency. Institut d'economie industrielle, Université des Sciences sociales de Toulouse.

Berger, A. N. (1995). The relationship between capital and earnings in banking. Journal of Money, Credit and Banking, 27, 432-456. http://dx.doi.org/10.2307/2077877

Chami, R., \& Cosimano, T. (2003). The nature of capital adequacy constraints under the Basel accord. Working Paper Series. Retrieved from http://ssrn.com/abstract=456981

Chen, J. (2003). Capital adequacy of Chinese banks: evaluation and enhancement. J. Bank. Reg., 4(4), 320-327. http://dx.doi.org/10.1057/palgrave.jbr.2340149

Dowd, K. (1999). Does Asymmetric Information Justify Bank Capital Adequacy Regulation? Cato Journal, 19(1), 39-47.

Ghoshi, S., Nachane, D. M., \& Sahoo, S. (2003). Capital requirements and bank behavior: an empirical analysis of Indian public sector banks. J. Int. Dev., 15, 145-156. http://dx.doi.org/10.1002/jid.947

Gropp, R., \& Heider, F. (2007). What can corporate finance say about banks' capital structures? Working paper. Retrieved from http://www.wiwi.uni-frankfurt.de/schwerpunkte/finance /master/brown/177.pdf

Hanke, S. H. (2013). Basel's Capital Curse. Financial Nigeria: Development and Finance Journal, 5(54), 34 37.

Harold, S. (1999). Capital Adequacy: Will Risk-based Measurements Help? Credit Union Executive Journal, $39(6)$.

Hausman, J. A. (1978). Specification Tests in Econometrics. Econometrica, 46(6), 1251-1271. http://dx.doi.org/10.2307/1913827

Ho, S. J., \& Hsu, S. C. (2010). Leverage, performance and capital adequacy ratio in Taiwan's banking industry. Japan. World Econ., 22, 264-272. http://dx.doi.org/10.1016/j.japwor.2010.06.007

Jeff, L. (1990). Capital adequacy: The benchmark of the 1990's. Bankers'Magazine, 173(1), 14-18.

Koehn, M., \& Santomero, M. A. (1980). Regulation of Bank Capital and Portfolio Risk. The Journal of Finance, 35(5). http://dx.doi.org/10.1111/j.1540-6261.1980.tb02206.x

Marcus, A. J. (1983). The bank capital decision: a time series-cross sectional analysis. J. Finan., 38(4), $1217-$ 1230. $\quad$ Retrieved from http://www.jstor.org/discover/10.2307/2328021 ?uid=3738280\&uid=2129\&uid=2\&uid=70\&uid=4\&sid=21 104214622943

Mathuva, D. M. (2009). Capital adequacy, cost income ratio and the performance of commercial banks: the Kenyan scenario. Int. J. Appl.Econ. Finan., 3(2), 35-47. http://dx.doi.org/10.3923/ijaef.2009.35.47

Modigliani, F., \& Miller, M. (1958). The cost of capital, corporation finance and the theory of investment. Am. Econ. Rev., 48, 261-297.

Morgan, G. E. (1984). On the adequacy of bank capital regulation. J. Finan. Quant. Anal., 19(2), 141-162. http://dx.doi.org/10.2307/2330895 
Morrison, A. D., \& White, L. (2001). The role of capital adequacy requirements in sound banking systems. Oxford Fin. Res. Center Working Paper. FE-04. Retrieved from http://ssrn.com/abstract=270728

Navapan, K., \& Tripe, D. (2003). An exploration of the relationship between bank capital levels and return on equity. Proceeding of the 16th Australasian Finance and Bank. Conf. (AFBC'03). Palmerston North, pp. $1-15$.

Reynolds, S. E., \& Ratanakomut, S. G. (2000). Bank financial structure in pre-crisis east and south East Asia. $J$. Asian Econ., 11(3), 319-331. http://dx.doi.org/10.1016/S1049-0078(00)00062-2

Rime, B. (2001). Capital requirements and bank behavior: empirical evidence for Switzerland. J. Bank. Finan., 25, 789-805. http://dx.doi.org/10.1016/S0378-4266(00)00105-9

Santomero, A. M., \& Watson, R. D. (1977). Determining an Optimal Capital Standard for the Banking Industry. Journal of Finance, 32(4), 1267-1282. http://dx.doi.org/10.1111/j.1540-6261.1977.tb03325.x

Saunders, A., \& Wilson, B. (2001). An analysis of bank charter value and its risk constraining incentives. $J$. Finan. Serv. Res., 19, 185-195. http://dx.doi.org/10.1023/A:1011163522271

Sharpe, W. F. (1964). Capital Asset Prices: A Theory of Market Equilibrium under Conditions of Risk. Journal of Finance, 19(3), 325-342. Retrieved from http://www.jstor.org/stable/2977928

Song, I. (1998). Korean Banks' responses to the strengthening of capital adequacy requirements. Federal Reserve Bank of San Francisco. Working Paper (PB98-01). Retrieved from http://EconPapers.repec.org/RePEc:fip:fedfpb:98-01

Tanaka, M. (2002). How do bank capital and capital adequacy regulation affect the monetary transmission mechanism? Cesifo Working Paper. 799. Retrieved from http://ssrn.com/abstract id=348461.

Thampy, A. (2004). BIS capital standards and supply of bank loans. Working Paper Series. Retrieved from http://ssrn.com/abstract $=561723$

Toby, A. J. (2008). Monetary policy, capital adequacy regulation and banking system soundness in Nigeria: empirical research findings. J. Fin. Manag. Analy., 21(1). Retrieved from http://ssrn.com/abstract $=1268587$

Wooldridge, J. (2002). Econometric analysis of cross section and panel data. MIT Press.

Yu, H. C. (2000). Banks' capital structure and the liquid asset-policy implication of Taiwan. Pac. Econ. Rev., 5(1), 109-114. http://dx.doi.org/10.1111/1468-0106.00093

Yu, M. T. (1996). Measuring Fair Capital Adequacy Holdings for Banks. Global Financial Journal, $239-252$. http://dx.doi.org/10.1016/S1044-0283(96)90007-1

\section{Copyrights}

Copyright for this article is retained by the author(s), with first publication rights granted to the journal.

This is an open-access article distributed under the terms and conditions of the Creative Commons Attribution license (http://creativecommons.org/licenses/by/3.0/). 